\title{
Context of the beginning of tobacco use in different social groups
}

\author{
Edina Ferreira Panaino ${ }^{1}$ \\ Cássia Baldini Soares ${ }^{2}$ \\ Célia Maria Sivalli Campos ${ }^{3}$
}

Objective: analyze contextual aspects of the beginning of tobacco use in different social groups, from everyday representations about the act of smoking. Methods: five focus groups were conducted to promote discussion about the context of beginning of tobacco use, with groups of people who represented different patterns of social reproduction. The data analysis was based on the theory of social representations, which contextualizes how each group presents the tobacco consumption. Results: the contexts of the beginning of tobacco use were diverse, according to patterns of social reproduction; there were common representations to all groups, but there were also unique representations of each social group. Tobacco is represented as indispensable for groups in unstable social reproduction situations, and as an instrument of pleasure and stress relief for those who can access other material assets. Conclusions: the study contributed to exposing the concepts on tobacco consumption that are socially disseminated, which can serve as an instrument to planning programs and health actions.

Descriptors: Public Health; Tobacco; Social Class; Adolescent; Socialization.

\footnotetext{
${ }_{1}^{1}$ MSc, Professor, Universidade do Grande ABC, Santo André, SP, Brazil.

${ }^{2} \mathrm{PhD}$, Associate Professor, Escola de Enfermagem, Universidade de São Paulo, São Paulo, SP, Brazil.

${ }^{3} \mathrm{PhD}$, Professor, Escola de Enfermagem, Universidade de São Paulo, São Paulo, SP, Brazil.
}

Corresponding Author: Cássia Baldini Soares Universidade de São Paulo. Escola de Enfermagem

Av. Dr. Enéas de Carvalho Aguiar, 419

Bairro: Cerqueira César

CEP: 05403-000, São Paulo, SP, Brasil

E-mail: cassiaso@usp.br
Copyright $\odot 2014$ Revista Latino-Americana de Enfermagem This is an Open Access article distributed under the terms of the Creative Commons Attribution Non-Commercial License (CC BY-NC).

This license lets others distribute, remix, tweak, and build upon your work non-commercially, and although their new works must also acknowledge you and be non-commercial, they don't have to license their derivative works on the same terms. 


\section{Introduction}

Tobacco is a drug that is socially condemned today. The strongest arguments come from the health field and are associated with morbidity and mortality related to tobacco consumption ${ }^{(1)}$.

This study was based in the understanding that tobacco use is associated with the structure and dynamics of social formation and that the social contexts are not natural, but they refer to concrete conditions of social reproductions of the different social groups(2).

In this theoretical perspective, tobacco, as well other merchandise, follows a production process that has profit as its main propose. To stimulate consumption, the industry marketing relies on instruments that introduce into the social dynamic representations that characterize tobacco consumption as fundamental to conducting a life of full satisfaction. The messages addressed to different social segments explore various aspects, given the diverse possibilities of distribution and consumption, which account for the context of sociability in different social groups ${ }^{(2)}$.

A systematic literature review resulted in strong association between poverty and smoking prevalence, in an inverse relationship between income level and tobacco use ${ }^{(3)}$. It also showed that consumption was higher among individuals of social classes with difficulties in consumption of goods and services, as well as insertion in the formal job market. In contrast, the greatest opportunities for smoking cessation are among individuals of middle and upper classes, as evidenced in a qualitative study on the subject(4).

Studies conducted in different areas of socialization of young adults and teenagers, describe socioeconomic factors such as risk for the onset of tobacco use in adolescence: lower socioeconomic level, attending a public school, paid work and studying at night ${ }^{(5-7)}$.

The prevalence of tobacco consumption among Brazilian adolescents, a stage of life globally considered more susceptible to the beginning of this habit, is seen to be significant. The literature describes that the average age of initiation of tobacco use occurs around 13 years of age ${ }^{(5-8)}$. Although risk factors associated with the beginning of use are widely studied, the multifactorial perspective on context and representational aspects of beginning and maintenance of tobacco consumption is poorly studied, and that would highlight social determinants of consumption and actions that could focus on the problem in a more solid way. Understanding the social context related to smoking is an explicit concern in healthcare, since the sociological comprehension of the issues surrounding these contexts will better position the work in health(9).

The objective of this investigation was to analyze the context of the beginning of tobacco consumption in different social groups.

\section{Methods}

This was a qualitative study conducted with residents of Santo André/SP, a group of 63 men and women who were invited in their workplaces and/or study places, because they had or have a life habit of smoking. Participation was voluntary and all individuals signed an Informed Consent.

The work or study institutions formed the locus of the research. Five groups were composed of participants with different profiles of social reproduction, identified through a questionnaire with variables related to work and life of the subjects ${ }^{(10)}$.

The groups were comprised of people aged 17 to 53 years: 14 homeless individuals (G1); 16 workers of the program Generation of Work of Social Interest (GTIS) (G2); 15 students of vocational courses offered by the city council, and courses of Education for Young People and Adults (EJA) (G3); 12 students from a private university (Veterinary Medicine), with stable conditions of social reproduction (G4); six full-time students from a private university (Medicine), with greater stability in work and life (G5).

Qualitative data collection was performed through focus groups that lasted on average 60 minutes, coordinated by the researcher, using the following guiding questions: Why do you use tobacco? How was your life before you starting smoking? How was school? How were your friends? Lovers? How was leisure, what did you enjoy? The contents registered in the groups were recorded, transcribed and analyzed, based on the epistemological foundations of the dialectical and historical materialism ${ }^{(11)}$ and theory of everyday life representations ${ }^{(12)}$.

To understand the everyday life representations of a group, it must start with reality, because the lifestyle constitutes the daily life, source of development of its representations. Everyday life is natural, simple and without reflective requirements; it is regular, as regularity of life turns it in daily and natural(12). Theory of everyday life representations considers that the representations are derived from inherent limitations of the social relationships of an individual with his or her 
environment, given the division of social work, leading to representations that may be illusory ${ }^{(11,13)}$.

We sought to understand everyday life representations in the dialectical perspective, not as mere descriptions of the reality, but as result of the social position that the individual occupies.

The analysis was conducted throughout the confrontation of work or study contexts of the groups' participants (concrete conditions of social reproduction) and the statements that exposed their ideas about the beginning of tobacco use.

The steps followed to analyze the material were: strict and literal transcription of groups and comprehensive analysis of the participants' statements; assessment of the elements common to all social groups, related to the context of initiation of tobacco consumption; identification of everyday life representations about the beginning of tobacco use, capturing values and beliefs related to the onset of tobacco consumption.

The project was approved by the Ethics in Research Committee of the School of Nursing of USP, under No. $1015 / 2011$.

\section{Results}

\section{Characterization of groups according to conditions of social reproduction}

The following is presented, the characteristics of each group identified in the questionnaire ${ }^{(10)}$ :

- G1-Homeless individuals: people with very poor conditions of social reproduction, some worked in the informal market (cardboard collectors, stonemason helpers, among others), others received social security benefits, and others survived by begging;

- G2-Workers of frontline jobs: people with unstable conditions of social reproduction (worked in the paving sector of the city and in various types of activities in public schools for a period). These individuals' onset of work was early, they had studied, or were studying in the evening period. Most were heads of families and lived in houses located in slums, common yards or tenements;

- G3-Students of vocational courses and EJA: people with conditions of social reproduction leading towards stability, for the most part they were employed, with expectations of better qualification at the end of the vocational course (especially in the area of construction and EJA). Mostly heads of families, who paid rent;

- G4-Veterinary medicine students: people in stable conditions of social reproduction, of working families and of comfortable life. Two classes of students from a private university, one course at night. Only two were heads of households, and the majority resided in own homes and helped the family to pay the college fees;

- G5-Medical students: people with families of stable conditions of social reproduction, which fully paid the expenses of their children. They did not work and there were no heads of households.

\section{Everyday life representations that surrounded the beginning of tobacco consumption in different social groups}

To facilitate the understanding of the common social representations and those particular to the groups, we chose to present the results based on the context of each group. Some excerpts from transcripts of the focus groups will exemplify the analysis of the representations.

\section{Tobacco as a contestation of social institutions}

The excerpt below shows the beginning of tobacco consumption represented as confrontation with family, either in response to a negative opinion of the young by the family, or to demand family coherence.

It was to challenge, because in my house they used to say that I did drugs [...] steal [...] that I would do everything and I did not do anything. [...] You know what? I will enter the house smoking and I did [...] I felt an outburst. Because they said things that I didn't do. I did not speak or anything, Then, it was a relief $[\ldots]$. (G1 - homeless individual)

\section{Tobacco as part of the process of admiration and} affective identification in the family environment

Smoking was represented by positive memories of pleasurable situations with beloved family members, which became more evidenced in Group 2.

One thing that I always saw, my father and my mother $[\ldots]$ took work home, they were teachers [...] that was the image I had of them, my mother was a person that would go to the window and stopped, stayed there, she lit a cigarette with my father and stayed there at the window watching the clouds, but one thing that is always stuck in my head is the their feature and countenance, and in those five or ten minutes that they were smoking there. (G2 - workers of frontline jobs)

Witnessing in everyday life of family members smoking seemed to naturalize the habit, expressing itself in representations of admiration followed by desire and/or curiosity. Many contexts of initiation of smoking were identified as "following the steps" of admired and 
cherished family members, by young people of all social groups, such as the following excerpt.

I started [smoking] at thirteen, but at the time [...] why did I start? Because I saw my brother smoking and I found it beautiful. I wanted to follow my brother's footsteps. It was the thrill of doing what my brother did. (G1 - homeless individual)

\section{Tobacco as a mechanism for sharing experiences among peers}

From the recorded content it was observed that sociability in the environment of friends allowed the everyday representation of smoking as sharing experiences, in this context it was learned how to use tobacco, to take what was good from it. Although this representation was expressed in all social groups, there were differences related to the place of the young people's socialization in the diverse social groups.

I started smoking at the age of 19; my first experience with cigarettes was with colleagues [...]. (G1 - homeless individual)

The first time I smoked was in another country [...] I said that I would do something different. I was 16, I think. (G5 medical students).

\section{Smoking as an ideal image}

Among the agencies of socialization that mediate smoking is the media. Everyday representations of tobacco are impregnated with glamour, charm, success, power, rebellion. They were represented in all social groups, such as in the excerpts below.

[...] I saw those 20 year old men right in front, ahhh! I wanted it also. On television it was cool [...] I saw everybody smoking, women, men. I smoked, every different brand [...]. Advertising helped a lot; it was more for the charm, right? The advertisement of Marlboro, [...] that power thing [...]. (G1 -homeless individual)

At the time there were those advertisements on television, those beautiful things about cigarettes. So for us, to be chic at the time you had to smoke, something that is the opposite today. (G3 - students of vocational courses and EJA)

\section{Smoking as a sign of maturity and independence}

Among the various images related to tobacco consumption, attention is drawn to the representation of maturity, because tobacco provides the elements of a rite of passage from the adolescent world to the adult world, a situation that is more stable and has greater responsibility, expressed in Group 1.

I got home [...] with a pack of cigarettes in my pocket. [...] The first thing my father said was: "I will not forbid you from smoking, but you will have to work to support your addiction". [...] At that moment my father started treating me man to man. For me that experience led me to mature in life. (G1 - homeless individual)

\section{Smoking as an act of casualness, relaxation and pleasure}

After trying tobacco, some individuals expressed that they learned to take what tobacco brought that was good, developing positive sensorial connections with it. The representations were associated with stress relief mainly, but also the simple pleasure arising from a change in psycho activity.

It is possible to infer that among people with lower conditions of social reproduction ( $G 1)$, tobacco was one of the few resources for coping with stressful situations, which are likely to remain for a long time. Participants in Group 1 considered tobacco very pleasurable, one of the few objects available for making them feel good. They mentioned that, because it was a legal drug, they had no trouble in getting it. This is an important factor among them, since the everyday life of this group is full of discrimination, marginalization and humiliation, precisely because they live on the streets and are dependent on "favors" from the city and society.

To lower stress. So I will not do anything stupid, I go there and unload everything in the cigarette. [...]. (G1 - homeless individual)

On the other end (G5), situations of anxiety were restricted mainly to situations of academic life, minimized with investment of the student to meet the university requirements. Tobacco, for these young people, was used as an adjuvant therapy for coping with stress, a feature used punctually.

Then it came time for a test and I said: I will explode! I will smoke because I am stressed, scared to hell of having to repeat grades. Then, there are a lot of tests for me to do, so I smoke. It gives me that relief [...]. (G5 - medical students)

Among the participants of the intermediate groups (G2 and G3), tobacco consumption was expressed as a source of pleasure, as well as a resource for coping with stress and frustration, especially that generated at work.

Gives a sense of relief right? At that moment you forget $[\ldots]$, it is like everything around you collapsed, there was nothing else, just you and the cigarette. It is like a child in a playground, playing, kind of. (G2 - workers of frontline jobs)

I was hotheaded, so I lit a cigarette, gives me relaxation, brakes the ice. It happens [...] at the work and home, I smoke and it gives me relief, huh? (G3 - students of vocational courses and EJA) 
Group 4 refers to tobacco as a source of pleasure, revealing taking what is good from tobacco in moments of tension, anxiety, but also in normal day-to-day life.

I am a musician, I play percussion. Smoking is an escape valve, when you are very anxious, light a cigarette and that moment of lighting a cigarette and taking the first puff, the person relaxes, it seems like you forget the rest of the world. (G4 - veterinary medicine students)

\section{Dual and contradictory representation: tobacco is good and bad}

Prolonged consumption of tobacco brought, in some cases, problems to the health of users, leading them to a negative depiction of tobacco use, recrimination of consumption and even interruption of the habit. In contrast, smoking was also associated with positive attributes, which made the interruption or substitution of tobacco by another source of pleasure, a feeling desired by all and much associated with tobacco smoking, reported by the ones who tried it.

Participants in Group 1 had no access to the job market, they worked informally and related primarily on the streets, where smoking is not repressed; thus, the social exclusion held them together with the same addictions and daily afflictions, they tried to stop smoking, a task much harder for them than for other social groups.

In my case [...] I had nothing to do, [...] everybody drinking in the public square [...] and I could not find a place. [...] Then, I took a beer can and then the cigarette. [...] It gives that feeling of power, pleasure. (G1 - homeless individual)

Group 2 valued family formation and evaluated that expenses with tobacco hindered the family budget and they expressed concern about the example to be given to their children. The group reproached smoking during pregnancy and valued health care from the moment they had a family for which to provide care.

It took me a long time to stop. At the beginning I liked it, but $[. .$.$] all the money that I earned was all for cigarettes. And it$ was in the time of school. (G2 - workers of frontline jobs)

Group 3 members mentioned that tobacco cessation consisted of an unremitting struggle, in which it was necessary to leave behind the good that tobacco brings. The wear and tear suffered by the body over the period of tobacco use was more evident in this group.

Then I decided to stop, [...] I kept trying during one year [...] then, one day I put the pack of Hollywood on the top of the closet, and I kept starring at it and saying "I will not smoke anymore", and it worked, I stopped. (G3 - students of vocational courses and EJA)
Group 4 mentioned the shame of hiding the habit because it was not the expectation of the parents. This guilt and the desire were relevant to quitting smoking.

I am not saying that today my life is $100 \%$ great, but I don't smoke because of it. I already smoked [...], but never exposed it to my parents, I was ashamed, and they did not deserve to know that the education they gave me was not worth anything. (G4 - veterinary medicine students)

For members of Group 5, smoking was understood as a passenger habit, a characteristic of this student phase. Tobacco had a soothing function, but continued consumption was associated with risk of injury to health.

\section{Discussion}

Tobacco was part of everyday life for many families of the young people interviewed, mediating important affective memories. Many studies draw attention to the correlation between smoking and the presence of smokers in the family ${ }^{(6-8,14)}$.

This relationship is almost always handled by the preventative speech of a reductionist manner, facilitating the social construction of a set of negative ideas that linearly relate smoking in the family with tobacco use by adolescents. Accordingly, the impact on health practices has been simply to condemn the family.

The dip in the representations afforded by this work, allowed the establishment of a positive relationship between the smoking habit and the family, associated with admiration of a beloved family member. Also in this study, the presence of a smoking habit among relatives was most remembered by groups with higher socioeconomic instabilities, which is consistent with a literature review ${ }^{(3)}$.

A critical stance shows that simplistic accusatory speeches of family about the behaviors of children and young people is a recurring theme, especially in situations of social crisis $^{(15)}$. The functionalist thinking in health tends to credit the problems associated with young people to "dysfunctional families", in a way that a supposedly idealized family is called to solve the problems of socialization of young people, while concrete families are accused of ills of youth ${ }^{(16)}$. This interpretation of the phenomenon, rather than encouraging planning practices, leads to impotence and immobilization of healthcare workers ${ }^{(17-18)}$.

The family tends to stay in the background, as the stronger participation comes from other institutions of socialization in the life of the young man, who starts to interact with peers, such as in the school and the street. 
In fact, the street belongs to the world of urban sociability, which interacts with other socializing institutions. The streets of cities belonging to metropolitan areas, such as Santo André, become workspaces, housing and many times, places of violence and drug use. But also, in the dialectical opposite reality, the streets end up being a leisure space for many young people, also one for creative expression, as it is with the spread of RAP groups in the city of São Paulo(19), that critically denounce carelessness with peripheral areas(20).

This research showed that all youth groups tended to socialize in different spaces of the family environment. In groups 1, 2 and 3, the spaces of socialization were restricted, due to the strong constraints arising from social situation of the families, leaving the street, and sometimes school, as the meeting point for affective exchanges among peers.

Group 3 was the one with largest number of participants who started smoking when already engaged in the job market. Some individuals in this group were enrolled early in the job market, living with older workers who already had a smoking habit, and smoked in the workplace and during study at night(21).

A multifactorial epidemiologic study established the risk relationship between going to school at night and a smoking habit(22). Another study revealed that tobacco use was higher among students who were working (13.6\%). Among those who did not work, there were $7.3 \%$ who were smokers ${ }^{(23)}$. The results of these studies described possible correlations, quantified factors that were associated with the onset of tobacco use, but did not consider the contexts. It was noted that hardly any of the studies rearticulated variables, allowing the understanding that studying at night was related to entering the labor market, with apparent maturing of the young person, who decided to adopt habits considered adult, and who had the possibility of wage gains, which provided conditions for tobacco consumption.

In all groups, tobacco use occurred in periods of increased stress, however the triggers constituted different situations: in groups 1, 2 and 3, stress was linked to conflictual situations with other people, with the work or disappointment of not reaching a proposed objective; in groups 4 and 5, the stress described was related to the pressure of daily work development or carrying out individual projects, such as earning a college degree. It can be inferred that among the participants of social groups with greater difficulties in social reproduction, tobacco use was important, wanted and needed to face the vicissitudes of everyday life. The participants of groups with greater access to wealth could think of tobacco as a transitional habit, which could be replaced by healthier resources to cope with exhaustion.

\section{Conclusions}

In this study, we sought to understand the relationship between different social contexts and beginning of smoking by means of everyday representations. It can be concluded that: within the family, issues involving affection and admiration came to light, beyond dispute, becoming elements which allowed users to overcome the simple condemnation of the family in the development of smoking habit. These results open the way for education about tobacco overcoming the usual criticisms, which only deal with constraining answers in place of reflective answers.

The initiation to tobacco occurs strongly outside the family spectrum, leaving the other instances of socialization, presenting this drug that is found in all social spaces, but which penetrates more freely in the streets, which are places of local abandonment, while, at the same time, are occupied by young people who, contradictorily, bring many dissonant voices for art and creation. Thus, the condemnation of the street as a living space in the messages on tobacco should be reconsidered because it is a concrete space of socialization for many.

It is also possible to conclude that tobacco is represented as an indispensable companion for the poorest social groups, and as an instrument of pleasure and relief of transient stress and likely of replacement for those who can access other material and cultural assets that fulfill the same function or outweigh the duties placed on the smoking habit.

This study did not aim to consider the gender category to understand the representations of onset of tobacco consumption, which could be the object of further studies in the area. The study contributes to exposing the concepts that are socially disseminated on tobacco consumption, which can serve as an instrument for planning programs and educational activities in health.

\section{References}

1. Pinto M, Ugá MAD. Os custos de doenças tabacorelacionadas para o Sistema Único de Saúde. Cad Saúde Pública. 2010;26:1234-45.

2. Soares $C B$, Campos CMS. Consumo de drogas. In: Borges ALV, Fujimori E, organizadoras. Enfermagem e a saúde do adolescente na atenção básica. São Paulo: Manole, 2009. p. 436-468. 
3. WHO. Systematic review of the link between tobacco and poverty/[project leader]: Agustín Ciapponi. Work conducted for WHO by the Institute for Clinical Effectiveness and Health Policy (Instituto de Efectividad Clínica y Sanitaria - IECS), Argentine Cochrane Centre IECS, Iberoamerican Cochrane Network: World Health Organization; 2011.

4. Paul CL, Ross S, Bryant J, Hill W, Bonevski B, Keevy $\mathrm{N}$. The social context of smoking: A qualitative study comparing smokers of high versus low socioeconomic position. BMC Public Health.2010;10:211.

5. Barbosa VC Filho, Campos W, Lopes AS. Prevalence of alcohol and tobacco use among Brazilian adolescents: a systematic review. Rev Saúde Pública. 2012;46:901-17. 6. Silva GA, Valente JG, Almeida LM, Moura EC, Malta DC. Tabagismo e escolaridade no Brasil. Rev Saúde Pública. 2009;43(supl 2):48-56.

7. Pinto DS, Ribeiro AS. Variáveis relacionadas à iniciação do tabagismo entre estudantes do ensino médio de escola pública e particular na cidade de Belém-PA. J Bras Pneumol. 2007;33:558-64.

8. Souza DPO, Silveira DX Filho. Uso recente de álcool, tabaco e outras drogas entre estudantes adolescentes trabalhadores e não trabalhadores. Rev Bras Epidemiol. 2007; 10:276-87.

9. Poland B, Frohlich K, Haines RJ, Mykhalovskiy E, Rock M, Sparks R. The social context of smoking: the next frontier in tobacco control? Tob Control. 2006 Feb; 15:59-63.

10. Trapé CA. Operacionalização do conceito de classes sociais em epidemiologia crítica: uma proposta de aproximação a partir da categoria reprodução social. [tese doutorado]. Faculdade de Enfermagem da Universidade de São Paulo; 2011.

11. Soares CB, Santos VE, Campos CMS, Lachtim SAF, Campos FC. Representações cotidianas: uma proposta de apreensão de valores sociais na vertente marxista de produção do conhecimento. Rev Esc Enferm USP. 2011;45(spec 2):1755-9.

12. Viana N. Senso Comum, representações sociais e representações cotidianas. Bauru: EDUSC; 2008.

13. Peixoto MA. As representações cotidianas do trabalho doméstico. In: Martins DC, Mattos IM, Soares MV, organizadores. Região e poder. Goiânia: Ed. PUC; 2010. 14. Vazquez FC, Pillon SC, Cuamatzi MT. Percepcíon de los estudiantes de enfermeria em cuanto al comportamiento de fumar em México. Texto Contexto Enferm. 2004;13:203-8.

15. Birman J. Adolescência sem fim? In: Cardoso MR, Marty F. organizadores. Destinos da adolescência. Rio de Janeiro: 7 letras; 2008. p. 81-105.
16. Lachtim SAF, Soares CB, Campos CMS, Coelho HV, Moreira CR, Silva SM. Valores sociais atribuídos à família por jovens de diferentes grupos sociais. Estácio de Sá - Ciências da Saúde. Rev Fac Estácio de Sá. [Internet]. 2012 [acesso 13 jan 2013];2:216-27. Disponível em: http://www.saps.com.br/sites/estacio/downloads/ revista/07_cienciadasaude_2012.1_atual.pdf

17. Soares CB, Campos CMS, Leite AS, Souza CLL. Juventude e consumo de drogas: oficinas de instrumentalização de trabalhadores de instituições sociais, na perspectiva da saúde coletiva. Interface. 2009;13:189-99.

18. Soares CB, Campos CMS, Berto JS, Pereira EG Avaliação de ações educativas sobre consumo de drogas e juventude: a práxis no trabalho e na vida. Trabalho, Educ Saúde. 2011; 9:43-62.

19. Sposito MP. A sociabilidade juvenil e a rua: novos conflitos e ação coletiva na cidade. Rev Sociol USP. 1994;5:161-78.

20. Silva VGBD, Soares C B. As mensagens sobre drogas no rap: como sobreviver na periferia. Ciênc Saúde Coletiva. 2004;9:975-85.

21. Lachtim SAF, Soares CB. Values attributed to work and expectations for the future: how young people position themselves? Trabalho Educ Saúde. 2011;9:277-94.

22. Borges MTT, Barbosa RHS. Cigarro "companheiro": o tabagismo feminino em uma abordagem crítica de gênero. Cad Saúde Pública. 2008;24:2834-42.

23. Martínez JAS, Ribeiro CRO. The search for equality: representations of the smoking act among adolescent women. Rev. Latino-Am. Enfermagem. 2008;16(esp):640-5 